\title{
Legal Problems Concerning Implementation of Sustainable Ecotourism in Russia
}

\author{
Wyzwania prawne odnoszące się do \\ wprowadzania ekoturystyki w Rosji
}

\author{
Svetlana Ivanova \\ Orenburg State Agrarian University, Land Law and Labor Law Department, \\ Russian Federation \\ E-mail: svetlana.ivanova.osau@gmail.com
}

\begin{abstract}
This paper proposes a fresh look at ecotourism within the framework of sustainable development. The author discusses selected issues involved in the sphere of ecotourism and proposes new ways to improve its current practice in Russia. Answers to questions of the nature, significance, and consequences of ecotourism, the relationship between sustainable development and ecotourism, and the problems of sustainable use of wildlife have been given. The comparative study of practical experience in facilitating ecotourism initiatives overseas has allowed the author to argue their conclusions and recommend a specific scientific approach to the sustainable use of wildlife in Russia.
\end{abstract}

Key words: ecotourism, sustainable development, the balance of convenience, sustainable use of wildlife, game resources

\section{Streszczenie}

W artykule zaproponowano nowe spojrzenie na ekoturystykę w kontekście zrównoważonego rozwoju. Autorka omawia wybrane zagadnienia z zakresu ekoturystyki i proponuje nowe sposoby doskonalenia jej dotychczasowych praktyk w Rosji. Przedstawiono propozycje odpowiedzi na pytania dotyczące natury, znaczenia i konsekwencji ekoturystyki, relacji między zrównoważonym rozwojem a ekoturystyką oraz problemów zrównoważonego użytkowania dzikiej przyrody. Analiza porównawcza praktycznych doświadczeń zagranicznych inicjatyw ekoturystycznych pozwoliła autorce zaproponować nowe naukowe podejście do zrównoważonego użytkowania dzikiej przyrody w Rosji.

Słowa kluczowe: ekoturystyka, zrównoważony rozwój, równowaga, zrównoważone wykorzystanie dzikiej przyrody, zasoby gatunków dziko żyjących

\section{Introduction}

Ecotourism is an effective way to implement the principles of sustainable development. Overseas, the potential of ecotourism as a useful tool for sustainable use is so great that nowadays a lot of states, especially developing countries, include it into their long-term plans for economic development. Today, ecotourism is one of the most promising and rapidly developing sectors of the tourism industry in foreign countries, holding one of the key positions. According to many experts, the share of ecotourism accounts for more than $10-20 \%$ of the profits from the entire tourist market (Lapochkina, Kosareva, Adashova, 2016).

Tourism contributes significantly to ensuring sustainable socio-economic development and social stability. This industry is crucial for the development of small businesses and micro-enterprises, generating employment, and also encourages self-employment. Ecotourism operates as a facilitator for the development of municipalities by providing alternative livelihoods for the local community. Today, tourism forms 3.4 percent of the gross domestic product in Russia, affecting 53 related industries. Each job created in the sphere of tourism entails the creation of 
up to 5 workplaces in such sectors of the economy as agriculture, forestry, and fishery (On Approval of the Concept of the Federal Target Program Development of Domestic and Inbound Tourism in the Russian Federation (2019-2025). The growing interest in ecotourism encourages the state to create and develop a system of specially protected natural areas, reserves, national parks, and wildlife reserves. These territories are the primary objects of Russian ecotourism. In 2017, about 9 million tourists visited national parks in Russia, and other 2 million tourists visited wildlife reserves (Skory, 2018).

National parks and a system of specially protected natural areas should be available to the public. It is ecotourism that allows for catering to the environmental, economic and social needs of the state and the population. Balancing economic and social interests, when using rare, endangered animal species in specially protected natural areas (hereinafter referred to as SPNA), can carried out through the organization of ecotourism.

Russia is a vast country, with unique nature monuments, invaluable national reserves, and outstanding potential tourist sites, but it still does not hold a leading position among countries specializing in ecotourism. In particular, today the share of ecotourism in the overall structure of the Russian tourist market is about 1 percent (Anisimov, Ryzhenkov, 2014). One of the reasons for the underdevelopment of this industry in Russia is the poor infrastructure of ecotourism in specially protected natural areas (sometimes there is no infrastructure at all) and inadequate resourcing of programmes in ecotourism.

In this regard, opinions and decisions proposed in this article can be used by representative and executive bodies of Russia and representatives of business in developing new plans and strategies in the field of sustainable use and conservation of wildlife objects. This article may also be of interest to environmental lawyers researching the development of ecotourism, as well as ordinary citizens interested in the development of ecotourism in Russia and abroad.

\section{Concept and elements of ecotourism: an in- ternational aspect}

Tourism is one of the most critical areas in the modern economy, aimed at meeting the needs of people and improving the quality of life of the population, which at the same time does not deplete the earth's natural resources. In recent years, ecotourism has been especially popular around the world. The distinctive features of ecotourism are that it simultaneously focuses on preserving wildlife and socio-economic development of the state and society.

One of the most critical factors determining the popularity of ecotourism is the concern of the entire world community about the conservation of the environment and its components. Humanity has be- come aware of the relationship between tourist revenues and the safeguarding of natural resources. Visitors to specially protected natural areas feel satisfied that their visit can assist in the preservation of a unique natural landscape or some wildlife species. Thus, getting ecotourism services, each person makes their contribution to the conservation of wildlife.

Tourism is a very complex activity and, therefore, requires the availability of legal instruments that ensure the implementation of economic, social and environmental requirements of sustainable development. One such tool is international treaties on the tourist industry. No doubt, Agenda 21 policy paper was one of such first international instruments (United Nations Conference on Environment and Development, 1992). Although tourism was not included as a separate topic into that document, later on, World Travel and Tourism Council (WTTC) and Earth Council developed and adopted a document entitled Agenda 21 for the Travel and Tourism Industry on its basis (World Travel and Tourism Council, World Tourism Organisation and Earth Council 1995). This document identified such principles for the development of tourism as the promotion of preservation, protection, and rehabilitation of ecosystems, the participation of local people in the tourism process, support of culture and interests of indigenous communities. In such a manner, Agenda 21 for the Travel and Tourism Industry has become the basis for the formation of ecotourism not only as a segment of the tourist market but also as a whole philosophy.

From the standpoint of philosophy, ecotourism is a vivid example of the combination of nature, sport, and ecology to promote spiritual and physical development of a person.

So far, ecotourism has formed the basis of some critical official international declarations: the Charter for Sustainable Tourism (1995), the Berlin Declaration on Biological Diversity and Sustainable Tourism (1997), the Global Code of Ethics for Tourism (GCET) (1999), and the Quebec Declaration on Ecotourism (2002). The principles and conditions of sustainable ecotourism were also developed in the United Nations Environment Programme (1995), the Seville Strategy for Biosphere Reserves (1995), the UNEP Principles of Environmentally Sustainable Tourism (2000) and other international instruments. Thus, the norms of international instruments in the field of sustainable development and sustainable forms of tourism have become useful tools in implementing the principles of ecotourism.

The analysis of the above-mentioned international instruments leads to the conclusion that the essential components of ecotourism are:

- education of tourists, i.e., the creation of educational tourism products with an environmental focus, aimed at in- 
creasing knowledge about nature and its components;

- preservation of ecosystems, which involves the careful use of resources on the route;

- $\quad$ participation of tourists and tour operators in campaigns to protect wildlife; respect for the customs and traditions of local communities, which results in intercultural exchange (Lapochkina, Kosareva, Adashova 2016).

There are a lot of generally accepted definitions of ecotourism in the scientific literature. Their analysis provides a clear picture of its main features. The Mexican environmentalist Héctor Ceballos-Lascuráin first formulated the term ecotourism. Initially, this term was used to study the environment and its components based on travel to protected areas with educational purposes. Thus, ecotourism was seen as an environmentally responsible travel and visitation to relatively undisturbed natural areas, in order to enjoy, study and appreciate nature (...) that promotes conservation, has low negative visitor impact, and provides for beneficially active socio-economic involvement of local populations (Ceballos-Lascuráin, 1996).

Subsequently, ecotourism is getting associated with the category of sustainability. From this point of view, ecotourism is a natural ecologically sustainable tourism, which includes research and analysis of the natural environment and its components. This definition recognizes that natural ecotourism is aimed at studying components of the environment.

Moreover, sustainable tourism implies receiving appropriate profits by the local population and the long-term conservation of wildlife (Review of Nature Based Tourism, 2007). Thus, ecotourism focuses on the enhancement and maintenance of natural ecological systems.

At the same time, ecotourism is considered to be a particular form of tourism, within the framework of which a specific area of wildlife is explored, including the local culture of the community in this area. Ecotourism involves non-consumptive use of wildlife and contributes to the preservation and development of the visited area through payment for services rendered (Ziffer, 1989). Such a definition of ecotourism is based on the following characteristics: 1) it includes a travel to relatively undisturbed natural zones; 2) its focus is on the study of wild animals and their habitats; 3 ) ecotourism is economically beneficial to the local population; 4) ecotourists do not deplete natural resources, but support the environment; 5) ecotourism aims to educate tourists in keeping with the spirit of values and respect for the culture and traditions of the local population (Chesworth, 1995).

Although the authors distinguish between various attributes of the ecotourism concept, most of its definitions come down to the existence of three criteria denoting the essence of ecotourism. In particular, ecotourism provides for environment conservation; includes meaningful community participation; is profitable and can be self-sustained (Kiper, 2013).

As a result, ecotourism is based on conceptual provisions observing the balance of environmental, economic and social interests of society, state, and business. The advantages of ecotourism could be provided as follows: 1) ecotourism activities are most often carried out within the boundaries of specially protected natural areas; 2) ecotourism contributes to the preservation of components of the environment and sustainable use of natural resources; 3 ) as part of ecotourism, the necessary financial resources are accumulated to ensure permanent wildlife conservation; 4) ecotourism allows to meet economic and social needs of the local population; 5) it is directed to the environmental education of people; 6) ecotourism should include conditions for the effective longterm management of the infrastructure, with minimal impact on biological diversity.

The indicated advantages of ecotourism can become a sufficient incentive for business entities in terms of developing and improving the implementation of tourist services, as well as for those entities that are only planning to organize their business in the field of ecotourism.

\section{Ecotourism as a measure of ensuring sustain- able use of wildlife: international and Rus- sian best practices}

Sustainable use of wildlife resources, including wild animals, significantly complements economic development and its opportunities worldwide. Ecotourism is an integral part of sustainable tourism. Ecotourism should be seen as a useful tool for implementing the sustainable development conceptual framework. For example, in many countries of Western Europe and developing countries ecotourism is perceived as an element of economic development and is seen as a measure to preserve wildlife.

The purpose of ecotourism is the preservation of wildlife objects, implementation of sustainable use of wildlife resources, conservation of their habitat and the acquisition of economic and social benefits. Therefore, tourism can be sustainable if its development meets the needs of tourists and local communities, protecting the biodiversity of the animal world. Thus, it is noted that sustainable ecotourism mainly protects natural areas, contributes to the preservation of biodiversity and ensures the sustainable use of rare species of wild animals. Otherwise, sustainable use may result in the reduction or even the destruction of certain species of wild animals or their habitat. This happened in the Himalayas when the number of tourists had increased by more than 25 times. Residents started actively cutting down the forest for heating campgrounds and numerous hotels. The mountain ranges, which had been covered by rose 
bay shrublets several years before, turned into barren wastelands, the paths were littered, and the populations of many animals and birds declined. However, there are not so many absolutely positive examples of ecotourism development in the world. Primarily and mainly, one can talk about the successful implementation of certain specific principles of ecotourism (Bochkareva, 2007).

Ecotourism is designed to ensure not only the sustainable use and preservation of wildlife in specially protected natural areas but also the sustainability of the tourist activity itself. Positive aspects of ecotourism development include the following: preservation of wildlife objects and their habitat, creation of new jobs for the local population, increased investment in infrastructure, growth in the well-being of the local people, and development of local self-government. Along with the positive aspects of ecotourism, in the context of developing the idea of sustainable use of wildlife objects, some challenging issues should be resolved. Thus, in practice, the discrepancy between the declared tourist programs and the principles of ecotourism is revealed; attracting management personnel from the outside, which results in the lack of motivation in the local population; creating conditions for tourists that worsen rather than support the environment; curbing of economic and cultural life for the sake of tourist needs (Bochkareva, 2007). Therefore, ecotourism grows at a sustained pace when tourists follow its principles and all ecological paths and routes are checked and classified into tourism categories, individual routes, and environmental tours. These ecotourism routes should be protected from mass tourism and based on the principles of sustainable tourism.

Providing an alternative source of livelihood for local communities, ecotourism assists in the development of rural settlements. The purpose of sustainable ecotourism is to preserve wildlife and its habitat, ensure sustainable use of wildlife and generate income in the provision of tourism services. Ecotourism allows for involving the local population into the conservation of biological diversity and environmental protection.

Sustainable tourism is based on three targets: quality, optimal exploitation, and the combination of interests of the state, business, and population. In particular, quality means that tourism should influence the quality of life for all participants in the tourism process. Optimal exploitation implies the exploitation of natural resources to ensure their recovery. The combination of interests of the state, business and population means that the balance of distributing benefits between participants of the tourism process should be fair (Mukhambetov et al., 2014).

Thus, ecotourism can be sustainable if the implementation of its services meets the needs of tourists and residents, while ensuring the protection of natural objects for the present and future generations. Sustainable ecotourism focuses mainly on studying the biological diversity of the animal world, its habitat, exploring natural ecological systems, as well as preserving the cultural heritage of the local population. According to some scientists, ecotourism model involves a combination of environmental activities and tourism in order to obtain financial benefits for local communities, with particular emphasis on sustainability (Witt, Merwe, Saayman, 2011).

In comparison with other countries, which should be looked up to, not a single type of tourism in Russia is adequately developed. The main problems hindering the development of ecotourism in this country should include the problem of fiscal federalism; national problems of SPNA boundaries and setting of standards regulating the development of ecotourism in Russia (Tsvigun and Vasilyev 2013). It is necessary to agree with the authors' opinion and add that the problem of organizing and developing ecotourism also consists in the lack of motivation, desire, and proper financing. Similar problems of ecotourism development are observed in Kazakhstan (Kairova, Esimova, Malikova, 2018).

In the modern world, people have long learned to sell the most absurd and, in fact, unremarkable objects. In this case, in Russia, nothing needs to be invented; it is only necessary to prioritize the promotion of tourist facilities correctly with environmental, natural areas, in particular. There are also examples of developing countries that are highly popular among eco-tourists, including Kenya, Tanzania, Belize, Ecuador, Laos, and Nepal (Lapochkina, Kosareva, Adashova, 2016). For instance, in South Africa, $90 \%$ of the 1,052,000 tourists registered in the country in 1995 travelled to visit the national parks and generated an economic flux of R13 million. In Tanzania, wildlife tourism generates a global income of about US\$570 million a year (Chardonnet et al., 2002). Thus, wildlife has become the basis and support of the tourism industry.

In Russia, it is necessary to take into account the experience of other countries in the field of ecotourism. It should be noted that in some areas of the Russian Federation there is already a trend towards the development of ecotourism as a measure of ensuring sustainable use of wildlife. For example, in the Orenburg State Nature Reserve, within the framework of ecotourism, services are provided in the form of guided walks along ecological paths, where one can observe wild animals with all precautions taken to conserve rare, endangered species (Orenburg Conservancy Area, 2017). At the same time, users of wildlife objects transfer a certain amount of money to the institution (reserve) account for the services rendered; this money could later be used to finance measures to conserve rare, endangered species and restore their number. No doubt, the economic profit from ecotourism in the Orenburg nature reserve is small, but there is also a positive trend. Simultaneously with the development of infrastructure within the framework of ecotourism, the social interest of 
residents by providing them with jobs is being realized. If wildlife can be managed in such a way so that local people get substantial material benefits from this, they will most likely cooperate with travel agencies and take measures to protect the environment (Mikhailova, 2010). At the same time, despite the significant increase in the number of tourists in nature reserves and national parks, Russia still cannot compete with other countries and is clearly inferior to them in the organization of ecotourism in specially protected natural areas.

As a result, ecotourism is a useful measure of legal support for the sustainable use of wildlife. Unlike other countries, this idea did not go any further in Russia. However, in some regions of Russia, the development of ecotourism provides a balance of environmental, economic and social interests of citizens and the state within the framework of the concept of sustainable development concerning rare, endangered species of animals. At the same time, ecotourism provides additional income and incentive for the sustainable use of wildlife objects, since all activities and services carried out in the field of ecotourism should be carried out on a sustainable basis in order not to cause excessive harm to rare, endangered species, damage to their habitats from overuse and pollution.

\section{Hunting tourism in Russia: problems and so- lutions}

Sustainable use of environmental components is an essential principle that has been recognized worldwide as useful for the conservation of natural resources and biodiversity. At the International Congress of the International Union for Conservation of Nature (IUCN), held in Amman in 2000, it was stated that the sustainable use of natural resources was one of the most important mechanisms for their conservation. Thanks to this approach, biodiversity is preserved in the long term and the needs of the state, business and society are met.

The Convention on Biological Diversity (1992) and The Addis Ababa Principles and Guidelines for the Sustainable Use of Biodiversity (2004) also indicate the need for the sustainable use of natural resources. According to some scientists, sustainable use does not exclude the protection of wild animals and the environment. The categories protection and use are two sides of the same coin (Baldus, Damm, Wollsheid, 2008). For example, a combination of protection and sustainable use of wildlife occurs when creating national parks. However, the use of resources and human interference, especially in specially protected natural areas, should be minimized.

In most specially protected natural areas, populations of wild animals need to be managed to balance their impact on other animal species and vegetation. Such processes of population management may include hunting. There are many options for using wild animals. In particular, they can be a source of food, a subject of commerce and trade, entertainment and tourism. Of all users of wildlife, hunting tourism is the most economically beneficial one. Hunting can provide an opportunity to receive relatively high incomes with the minimum withdrawal of individual game animals, most often aging males. The well-regulated take-off of 1 to $2 \%$ of prime or post-prime males does not damage the respective game populations. Also, relatively high revenues can be generated by few clients (Sustainable Hunting Tourism Position Paper of the CIC Tropical Game Commission, 2008). If revenues generated from sustainable hunting tourism are directed towards the conservation of wildlife resources, and the local population derives economic benefits from this, then this form of using natural resources can directly contribute to reducing rural poverty and will help to strengthen efforts to preserve wildlife. Thus, hunting tourism can give a significant impetus to the economic and social development of rural, remote areas. Hunting tourism can positively influence wild animals, their habitat, and also contribute to the social and economic support of the local population. Therefore, hunting tourism is widely recognized as an integral part of rural development. Hunting can provide income for nature conservation and, at the same time, be aimed at economic and social improvement of the quality of life for local people.

However, every step in the development of hunting and hunting tourism should have a wise and ecologically sustainable character, so that hunting tourism fulfills its role as a tool for positive management and as a powerful incentive to preserve hunting resources. For example, in Serbia, there are well-established programs for hunting as a type of tourism. This type of tourism requires strict observance of specific rules of conduct regarding border crossing, travel to hunting grounds, issuing weapons and ammunition permits, provision of qualified guides, registration of veterinary permits for exporting game and other rules. A hunting tourist can hunt and train hunting dogs at the hunting ground only with the mediation of an authorized agency which has entered into an agreement with the user of the hunting ground. A hunter must have issued permits on hunting weapons, telescopic sights, and ammunition, as well as hunting dogs. They have the right to shoot only those types of game that are specified in their hunting license, namely, with the permission of a qualified guide. Before the hunter can remove the shot game and its parts (trophy, meat, skin) from the hunting ground, he or she must make payment according to the price list of the hunting association (National Tourism Organisation of Serbia, 2018).

At the same time in the process of hunting tourism implementation, there are numerous abuses by hunters, representatives of tourist companies, state and municipal authorities. Among them are such adverse 
phenomena as corruption, fraud, overstatement ofshooting quotas, poor management and reduction in the number of wild animals, depletion of biodiversity. Negative examples of this kind can be found in any country in the world. So, in Belarus, not all hunters can afford to pay high prices for the services rendered as part of hunting tourism. For example, prices for hunting a European bison start from $€ 10,000$, as for the other animals, one can choose between a wild boar ( $€ 100-600)$, an elk ( $€ 700-4,500)$ or a red deer (€ 700-3,500).

Poaching continues to be a widespread activity for many hunters, especially in rural areas. Corruption thrives, as both local people and local power holders often make deals with forestry workers (Smok, 2015). At the same time, hunting tourism attracts a new wave of vandal tourists, who view hunting as a shooting club, and nature as a bottomless pit. Unfortunately, no travel agency is able to replace the team of a hunting society that can educate such a hunter in the spirit of a proper hunt (Polikarpova, 2003). It is estimated that there are about 15 million hunters in the United States alone. In North America, according to experts, about 175 million wild animals are annually killed by tourist hunters. In Botswana, entire hunting grounds of hunting-animal species have been destroyed by illegal hunters. In Italy, hunters illegally shoot populations of migratory birds in places where they breed and pass the winter.

In many countries, and primarily in developing countries, over the past 50 years, the volume of organized hunting tourism has rapidly increased. Hunting tourism has plenty of advantages for the host country and its rural population: preservation of ecosystems; income generation and job creation in poor and deprived areas; economic and rational use of habitats unsuitable for agriculture or conventional tourism; raising awareness of the local population concerning the value of wildlife, otherwise hunting tourism is associated with causing damage, problems, and costs; less harmful impacts on the environment than with other forms of tourism; less poaching through the concerted efforts of all who are interested in the revenues generated by hunting tourism (Sustainable Hunting Tourism Position Paper of the CIC Tropical Game Commission, 2008). Thus, hunting tourism gives a significant positive impetus to the economic and social development of remote, underdeveloped rural areas.

Hunting tourism, the primary purpose of which is to render services in the field of hunting, has already been quite firmly established in the practice of Russian hunting providers. Russia is visited annually by relatively few, no more than 2,000 hunters (Visloguzov, 2013). Hunting tourism is the most common activity in the Magadan region, Chukotka and other subjects of the Russian Federation. For example, at present, Yakutia may be of interest to a tourist-hunter with a Kolyma elk, a snow sheep, and a wild reindeer. At the same time, when organizing a hunt in those regions, a helicopter is often used, the cost of a one hour flight comes to 200 thousand rubles (more than $\$ 3,000$ ), and not all hunters can afford it (Makrushenko, Andreev, 2014).

Thus, such a hunt becomes uncompetitive with other services within the framework of hunting tourism. In this connection, in order to avoid significant expenses, hunting is often executed without licenses, which, in our opinion, speaks for insufficient work of the authorized government bodies, lack of proper control on their part and inadequate legislation. Also on the territory of Russia, there is an unreasonably complicated procedure for the temporary importation of hunting firearms into the country (Makrushenko, Andreev, [2008] 2009).

The solution of existing problems in this area will allow one to count on the sustainable development of hunting tourism and ensuring the sustainable use of hunting resources.

As a result, it should be noted that hunting tourism in Russia is at the stage of development. Unfortunately, the current legislation on hunting and legislation in the field of tourism do not ensure the sustainable use of hunting resources. The process of hunting tourism does not satisfy the social and economic needs of the local population. Organizing hunting tourism in the stationary shooting preserve, the hunting provider is interested only in receiving large incomes, and, very often, the local population cannot afford this kind of service. Therefore, such adverse phenomena as poaching and corruption take place. In this regard, it is necessary to formulate a development strategy for hunting tourism in Russia based on the principles of sustainable development and take into account the recommendations of the author of this article on improving legislation in the field of hunting and tourism.

\section{Conclusion}

The author views ecotourism as a measure for the legal provision of sustainable use and conservation of wildlife objects through the prism of sustainable development. Moreover, a system for adequate balancing of economic, ecological and social interests, aimed at solving some theoretical and practical problems in the field of sustainable use of wildlife, has been proposed. This approach will make it possible to move from the idea of ecotourism to that of sustainable ecotourism based on the principles of sustainable development and ensuring a balance of interests for the local population, business, and the state.

Developing ecotourism is a long-term process that requires constant efforts on the part of all agents, including the government, business, and society. Currently, for the development of ecotourism, it is necessary to adopt and ensure the phased implementation of the main directions and strategies for the development of ecotourism concerning all wildlife ob- 
jects. Therefore, the main advantages of ecotourism, such as the preservation of wildlife objects, can be obtained not immediately, but after a long period. Based on the analysis of individual provisions of the legislation on wildlife and law enforcement practice, the author argues that in Russia there are no criteria for sustainability in the field of ecotourism. According to the author, the following sustainable ecotourism criteria could be outlined: the conservation of historical areas of wild animals; increase in the number of populations of individual species of wild animals; active interaction between local people and ecotourists; creation of permanent jobs for the local population; development of other related industries. The criteria for sustainable use of wildlife developed by the author determine the conditions that should be fulfilled in order to confirm that wildlife objects are used sustainably.

\section{References}

1. ANISIMOV A.P., RYZHENKOV A. JA., 2014, Ecotourism Development, Environmental Policy and Law, 44(6): 545-565.

2. BALDUS R. D., DAMM G. R., WOLLSHEID K.-U. (eds.), 2008, Best Practices in Sustainable Hunting A Guide to Best Practices from Around the World, CIC Technical Publication Series No. 1, Hungary, http://www.fao.org/3/a-aj114e.pdf (20.12.2020).

3. BOCHKAREVA T. V., 2007, Ecotourism: Analysis of Existing International Experience, http://tourlib.net/statti_tourism/bochkareva.htm (18.12.2020).

4. CEBALLOS-LASCURÁIN H., 1996, Tourism, ecotourism and protected areas: the state of naturebased tourism around the world and guidelines for its development, IUCN, Cambridge.

DOI: 10.2305/iucn.ch.1996.7.en.

5. CHARDONNET PH., DES CLERS B., FISCHER J., GERHOLD R., JORI F., LAMARQUE F., 2002, The Value of Wildlife, Scientific and Technical Review, 21(1): 15-51, http://www.uesc.br/cursos/pos_graduacao/mestrado/animal/artigo_chandonet.pdf (26.11.2020).

6. CHESWORTH N., 1995, Ecotourism, Seminar paper delivered in the Institute of Environmental Studies and Management, UPLB. College, Laguna.

7. KAIROVA SH.G., ESIMOVA D.D., MALIKOVA F.M., 2018, Sustainable Ecological Tourism in Kazakhstan, Science and Tourism: Strategies of Interaction, 8: 27.

8. KIPER, TUĞBA, 2013, Role of Ecotourism in Sustainable Development, Advances in Landscape Architecture, ed. Ozyavuz M.,. Croatia: Intech Open Access Publisher, I-Tech Education and Publishing, Croatia.

9. LAPOCHKINA V.V., KOSAREVA N.V., ADASHOVA T.A., 2016, Ecological Tourism in Russia, Development Trends // International Scientific and Research Journal, 5(47), Part 1: 100-105.

10. MAKRUSHENKO V. V., 2014, Regional Features of Hunting Tourism in Russia, Agricultural Science Euro-North-East, 6(43): 50.

11. MAKRUSHENKO V. V., ANDREEV M. N. 2008, 2009, Those Who Come to Russia with a Gun (Temporary Importation of Hunting Weapons by Foreign
Citizens to Russia). Part I, Safari, 2008, 6: 40-43; Part II, Safari, 2009, 1: 68-71.

12. MIKHAILOVA M.N., 2010, Management of Tour Operating: to the Question of Foreign Representatives of Tour Operators, Pskov Regional Journal: 124-126.

13. MUKHAMBETOV T.I., JANGUTTINA G.O., ESAIDAR U. S., MYRZAKULOVA G. R., IMANBEKOVA B. T., 2014, The Life Cycle of Sustainable Eco-Tourism: Kazakhstan Case Study, WIT Transactions on Ecology and Environment, Almaty Technological University: 187.

14. NATIONAL TOURISM ORGANISATION OF SERBIA, 2018, Hunting Tourism, http://www.serbia.travel/activities/fauna-of-serbia/hunting.618.html (26.12.2018).

15. ORDER OF THE GOVERNMENT OF THE RUSSIAN FEDERATION N 872-p, May 5, 2018, On Approval of the Concept of the Federal Target Program Development of Domestic and Inbound Tourism in the Russian Federation (2019-2025), Consultant Plus computer-based legal research system.

16. Orenburgskij Conservancy Area, https://ria.ru/reserves/20170213/1487821837.html (25.01.2018).

17. POLIKARPOVA N. E., 2003, Problems of Hunting Tourism in Russia, in: Russian Hunting Newspaper, December 17, https://www.ohotniki.ru/editions/rog/ article/2003/12/17/122200-problemyi-ohotnichegoturizma-v-rossii.html (15.10.2020).

18. REVIEW OF NATURE BASED TOURISM, 2007, Report to the Minister for the Environment and the Minister for Tourism, https://parks.dpaw.wa.gov.au/ sites/default/files/downloads/know/Review\%20of\% 20Nature\%20Based\%20Tourism.pdf (19.11.2020).

19. SKORY R., 2018, The Development of Ecotourism in Russia. Foreign Practice. Russian Ecotourism, in: National Tourist Union, April 04, https://rusunion. com/razvitie-ekoturizma-v-rossii/ (19.10.2020).

20. SMOK V., 2015, Hunting Tourism and Corruption in Belarus, https://udf.by/english/featured-stories/1160 32-hunting-tourism-and-corruption-in-belarus.html (19.09.2020).

21. SUSTAINABLE HUNTING TOURISM POSITION PAPER OF THE CIC TROPICAL GAME COMMISSION, 2008, Best Practices in Sustainable Hunting - A Guide to Best Practices from Around the World, eds. Baldus R.D., Damm G.R., Wollsheid K.U., CIC Technical Publication Series No. 1, Hungary: 20-22, http://www.fao.org/3/aj114e/aj114e04. pdf (29.10.2020)

22. TSVIGUN I. V., VASILYEV A. YU., 2013, Problems and Development Prospects of Ecological Tourism in Russia, Irkutsk State Economic Academy Review, 6: 15-19.

23. UNITED NATIONS CONFERENCE ON ENVIRONMENT AND DEVELOPMENT, 1992, Agenda 21, Rio de Janeiro, Brazil, 3-14 June, http://www. un.org/ru/documents/decl_conv/conventions/agenda 21.shtml (16.11.2020)

24. VISLOGUZOV B., 2013, Hunting Tourism, https://www.svastour.ru/articles/ puteshestviya/vidyturov/okhotnichiy-turizm.html (29.08.2020).

25. WITT L. DE, VAN DER MERWE P., SAAYMAN M., 2011, An Ecotourism Model for South African National Parks, Book of Proceedings Vol. II - International Conference on Tourism \& Management Studies, Algarve: 1138-1142, https://www.research 
gatenet/publication/265582912_an_ecotourism_mod el_for_south_african_national_parks (27.10.2020).

26. WORLD TRAVEL AND TOURISM COUNCIL, LONDON; WORLD TRAVEL \& TOURISM COUNCIL; 1995, Agenda 21. For the Travel and
Tourism Industry: Towards Environmentally Sustainable Development, World Tourism Organization, San José, Costa Rica, Madrid.

27. ZIFFER K., 1989, Ecotourism: the uneasy alliance, Conservation International, Washington D.C. 